\title{
ON BRACONIDAE PARASITIC ON DIATRAEA SACCHARALIS IN DEMERARA.
}

\author{
By R. E. Turner.
}

Three species of Braconidae have now been bred in Demerara from the larva of the cane-boring moth, Diatraea saccharalis : Ipobracon grenadensis, Ashm., which I have previously mentioned (Ann. Mag. N.H. (8) xx, 1917, p. 244), and Ipobracon saccharalis, sp. n., both of which belong to the subfamily BracontNaE; and Microdus diatraeae, sp. n., which belongs to the subfamily AGathinaE.

\section{Ipobracon saccharalis, sp. nov.}

o. Niger ; segmentis abdominalibus 5 basalibus rufis; alis pallide fuscis, dimidio basali subhyalinis ; stigmate flavo, tertio apicali fusco, cellula cubitali prima striga obliqua hyalina; venis brunneis.

Long. $8 \mathrm{~mm}$.

6. Face and front closely and finely punctured, densely clothed with close-lying grey hairs ; vertex strongly convex, minutely punctured ; the head strongly narrowed behind the eyes. Antennae about 63-jointed ; the scape finely and closely punctured, the third joint distinctly longer than the fourth. Thorax and median segment very finely punctured, sparsely on the dorsal surface of the thorax, very closely on the mesopleurae and median segment, both of which are densely clothed with greyish pubescence, which is also present, though much more sparsely, on the dorsal surface of the thorax. Mesonotum narrowed anteriorly, the parapsidal furrows very deep. First tergite almost as broad at the apex as long, the lateral carinae well developed, the median area finely rugulose, the grooves between the median area and the lateral carinae broad and transversely rugulose. Second tergite with a smooth lanceolate area from the base reaching to the middle and prolonged by a carina to the apex ; the areae at the anterior angles large and smooth, the groove separating them from the remainder of the segment shallow and narrow; on each side of the median area are short oblique striae, beyond which the segment is finely rugose ; second suture broadly arched and finely crenulate. Third and fourth tergites finely punctured-rugulose; the third with a very small triangular smooth area at the base, the areae at the anterior angles large and smooth. Apical tergites very finely punctured. Nervulus interstitial; recurrent nervure received just before the first transverse cubital nervure.

British Guiana: Non Pareil Plantation, East Coast of Demerara, 6.iii.1913 (G. E. Bodkin).

This is a parasite on the larva of Diatraea. It is more nearly allied to I. poultoni, Szép., than to any other described species, but I do not think that it can be the male of that species owing to differences in sculpture, and in the form of the area on the second tergite. I. dolens, Cam., is also very nearly related, but the colour is different and the sculpture of the abdomen is finer, the fourth tergite being finely punctured, shining between the punctures, not rugulose, and there is no basal shining area on the third tergite; so that, unless the sculpture is subject to considerable variation, the two cannot belong to one species.

(C455) 
Microdus diatraeae, sp. nov.

ㅇ. Nigra ; segmento mediano, abdomine, segmento apicali excepto, coxis posticis, femoribusque posticis, apice excepto, rufo-ferrugineis, alis fuscis, stigmate cellulisque mediana cubitalibusque prima secundaque pallide flavis, palpis testaceis.

Long. $11 \mathrm{~mm}$. ; terebrae long. $12 \mathrm{~mm}$.

ㅇ. Face subopaque, finely and very closely punctured, much broader than long; vertex shining, sparsely punctured, front shining, concave, the marginal carinae of the concave area low and indistinct. Thorax strongly narrowed anteriorly, shining, the parapsidal furrows deep; the median lobe of the mesonotum almost smooth, with a distinct longitudinal carina, the lateral lobes distinctly, but rather sparsely punctured. Mesopleurae, sides of the median segment and coxae finely and very closely punctured. Median segment rather finely rugose at the base, becoming distinctly reticulate towards the apex, with two distinct, but not very strong, longitudinal carinae close to the middle, running from near the base to the apex. First tergite nearly twice as long as its apical breadth, twice as broad at the apex as at the base, irregularly obliquely rugose-striate, with a distinct longitudinal carina from the base to the middle, the apex smooth and shining. Second tergite nearly two-thirds of the length of the first, smooth and shining, with an oblique groove on either side from the base to the lateral margin, the space at the angle bounded by the grooves very small; a broad transverse groove crossing the segment near the middle, the groove closely longitudinally striated; second suture smooth. Third tergite smooth and shining, with a shallow, smooth, transverse groove which is obsolete in the middle ; the remaining segments smooth and shining. Spur of hind tibia scarcely more than one-third of the length of the hind metatarsus; ungues simple. Second cubital cell triangular, not petiolate; the radius reaching the costa a little nearer to the apex of the wing than to the apex of the stigma.

British Guiana : Lusignan, Non Pareil and Ogle Plantations, East Coast of Demerara; March and April (G. E. Bodkin).

A parasite of Diatraea larvae.

In the transverse grooves of the second and third tergites this approaches the genus Aërophilus, Szép., but the general form and the sculpture of the median segment approach much more nearly to Microdus. Nearly related to this species is Microdus maculipes, Cam., 1911 (Cremnops maculipes, nec Microdus maculipes, Cam. 1887), which I take to be the female of Microdus parvifasciatus, Cam. (described as a Cremnops); but the sculpture of the median segment and the difference in the length of the terebra separate the two species at once. Other species described by Cameron in the same paper as Cremnops and really belonging to Microdus are M. nigrobalteatus and $M$. punctipennis. 


\section{$2 \mathrm{BHL}$ Biodiversity Heritage Library}

1918. "On Braconidae parasitic on Diatraea saccharalis in Demerara." Bulletin of entomological research 9, 81-82. https://doi.org/10.1017/s0007485300037810.

View This Item Online: https://www.biodiversitylibrary.org/item/110215

DOI: https://doi.org/10.1017/S0007485300037810

Permalink: https://www.biodiversitylibrary.org/partpdf/49397.

\section{Holding Institution}

Smithsonian Libraries

\section{Sponsored by}

Biodiversity Heritage Library

\section{Copyright \& Reuse}

Copyright Status: Public domain. The BHL considers that this work is no longer under copyright protection.

This document was created from content at the Biodiversity Heritage Library, the world's largest open access digital library for biodiversity literature and archives. Visit BHL at https://www.biodiversitylibrary.org. 